\title{
Pengembangan modul fisika berbasis Scientific Approach untuk meningkatkan Keterampilan Proses Sains siswa
}

\author{
Eli Sumiati ${ }^{1}$, Damar Septian ${ }^{1}$, F. Faizah ${ }^{1}$ \\ ${ }^{1}$ Prodi Pendidikan Fisika, Universitas Nahdlatul Ulama Cirebon, Kota Cirebon, 45134, \\ Indonesia \\ E-mail: elisumiaty7@gmail.com; damar-septian@unucirebon.ac.id ; faizah@unucirebon.ac.id
}

Received: 2805 2018. Revised: 2108 2018. Accepted: 12092018

\begin{abstract}
Abstrak
Modul fisika berbasis scientific approach dikembangkan untuk meningkatkan keterampilan proses sains siswa yang disesuaikan dengan hakikat sains sebagai proses, karakteristik materi fluida statis, dan penggunaan kurikulum 2013 yang identik dengan scientific approach. Penggunaan modul ini bertujuan untuk mengetahui: (1) karakteristik hasil pengembangan modul fisika berbasis scientific approach, (2) keefektifan penggunaan modul fisika berbasis scientific approach dalam meningkatkan keterampilan proses sains siswa. Penelitian ini merupakan penelitian Research and Development (R\&D) yang mengacu pada model Four-D (4D). Data dari angket dianalisis secara deskriptif dengan persentase sedangkan data hasil keterampilan proses sains siswa dianalisis dengan uji t dua sampel berpasangan menggunakan software IBM SPSS Statistics 19, uji n gain score, dan uji effect size dari Cohen. Berdasarkan hasil analisis data disimpulkan: (1) karakteristik modul menyajikan materi yang meninjau aspek keterampilan proses sains (menginterpretasi, memprediksi, mengaplikasikan konsep, merancang percobaan, dan mengkomunikasikan); (2) modul memiliki nilai keefektifan sebesar $64 \%$ dalam kategori "efektif"dengan nilai effect size sebesar 1,32 dalam kategori "Besar".
\end{abstract}

Kata Kunci: modul fisika; Scientific Approach; fluida statis, Keterampilan Proses Sains

\section{Development of Scientific Approach-based physics modules to improve students' Science Process Skills}

\begin{abstract}
The physics approach based scientific approach was developed to improve student science process skills that are adapted to the nature of science as a process, the characteristics of a static fluid material, and the use of the 2013 curriculum that is identical to the scientific approach. The purpose of this module is to find out: (1) the characteristics of the development of a scientific approach based physics module, (2) the effectiveness of the use of a scientific approach based physics module in improving students' scientific process skills. This research is a Research and Development $(R \& D)$ research that refers to the Four-D (4D) model. Data from the questionnaire were analyzed descriptively by a percentage while the results of the students' science process skills were analyzed by two samples t-test in pairs using IBM SPSS Statistics 19 software, $n$ gain score test and Cohen's effect size test. Based on the results of the data analysis concluded: (1) the characteristics of the module presents material that reviews aspects of science process skills (interpreting, predicting, applying concepts, designing experiments, and communicating); (2) the module has an effective value of $64 \%$ in the "effective" category with an effect size of 1.32 in the "Large" category.
\end{abstract}

Keywords: physics module; Scientific Approach; static fluid, Science Process Skills 


\section{Jurnal Pendidikan Fisika dan Keilmuan (JPFK), 4 (2), 2018 - 76}

Eli Sumiati, Damar Septian, F. Faizah

\section{PENDAHULUAN}

Pendidikan harus selalu dikembangkan agar pendidikan menjadi lebih baik dan sesuai dengan tujuan (Septian, 2018). Pendidikan yang baik tentunya harus didukung dengan pembelajaran yang ideal. Kegiatan pembelajaran yang ideal merupakan sebuah harapan bagi setiap warga sekolah terutama siswa. Menurut Peraturan Pemerintah No. 19 Tahun 2005 pasal 42 ayat 1 dan 2 tentang standar sarana prasarana pendidikan bahwa setiap satuan pendidikan wajib memiliki sarana yang meliputi perabot, peralatan pendidikan, media pendidikan, buku, dan sumber belajar lainnya serta perlengkapan lainnya yang diperlukan untuk menunjang proses pembelajaran yang teratur dan berkelanjutan (Indonesia, 2005).

Menurut Megasari (2014), keberadaan sarana prasarana pendidikan dibutuhkan dalam proses pendidikan, sehingga termasuk dalam komponen yang harus dipenuhi dalam pelaksanaan proses pendidikan (Mulyanto, 2016). Sarana prasarana merupakan salah satu item Standar Nasional Pendidikan. Menurut Tu'u, sarana belajar biasanya menjadi penunjang prestasi belajar, namun apabila tidak memadai dapat menjadi penghambat (Giantera, 2013). Semakin banyak peserta didik disuguhkan dengan berbagai media dan sarana prasarana yang mendukung, maka semakin besar kemungkinan nilai-nilai pendidikan mampu diserap dan dicernanya (Arsyad, 2011).

Fluida statis merupakan materi fisika untuk SMA kelas XI. Kompetensi dasar dalam materi fluida statis yaitu menerapkan hukum-hukum fluida statis dalam kehidupan sehari-hari, merencanakan dan melakukan percobaan yang memanfaatkan sifat-sifat fluida statis, berikut presentasi hasil dan makna fisisnya. Karakteristik fluida statis merupakan materi yang bisa diamati oleh siswa secara langsung yang banyak berkaitan dalam kehidupan sehari-hari. Sehingga penting untuk dipahami siswa (Herdianto, 2014). Pembelajaran fluida statis dianggap kurang berhasil bila tidak ditunjang dengan kegiatan praktikum/ laboratorium (Yuliani, 2012). Proses pembelajaran fisika yang tepat tentunya akan menghasilkan siswa yang unggul dan berkarakter (Satria \& Handhika, 2015). Beberapa ilmu fisika (yang merupakan bagian dari ilmu sains) membutuhkan pengilustrasian dalam pembelajarannya agar materi mudah dipahami (Septian, Cari, \& Sarwanto, 2017). Fisika merupakan bagian sains. Sains merupakan hasil produk ilmu yang ilmiah, sehingga metode, proses, prinsip, sikap dan lainnya juga harus ilmiah. Oleh karena itu, pembelajaran fisika di sekolah seharusnya juga dilakukan dengan pendekatan ilmiah (scientific approach) agar lebih bermakna dalam benak siswa dan mampu membentuk sikap atau karakter siswa.

Scientific approach sangat erat kaitannya dengan keterampilan dan karakter siswa, yaitu karakter yang didasarkan pada sikap ilmiah seperti kerja keras, disiplin, jujur, terbuka, demokratis, kreatif, cermat, teliti, komunikatif dan bertanggungjawab (Satria \& Handhika, 2015). Sains dan pembelajaran sains tidak hanya pengetahuan yang bersifat ilmiah saja, melainkan terdapat dimensi-dimensi ilmiah penting yang menjadi bagian sains selain muatan sains salah satunya adalah proses dalam melakukan aktivitas dan sikap ilmiah sains yang disebut keterampilan proses sains (Tawil \& Liliasari, 2014). Salah satu maksud dari pengembangan kemampuan yang dimiliki oleh siswa dalam keterampilan proses sains adalah memberi kesempatan kepada siswa bekerja dengan ilmu pengetahuan, di sisi lain siswa merasa bahagia sebab mereka aktif (Tawil \& Liliasari, 2014). Oleh karena itu, keterampilan proses sains penting untuk dikembangkan agar siswa menjadi pembelajar yang aktif.

Menurut Semiawan, beberapa alasan pentingnya meninjau keterampilan proses sains dalam pembelajaran sains diantaranya adalah peserta didik lebih memahami konsep yang rumit dan abstrak jika disertai dengan contoh yang konkret (Arumsari, Rosilawati, \& Kadaritna, 2016). Beberapa hasil penelitian menunjukkan bahwa ada pengaruh dalam prestasi afektif, sikap ilmiah, dan kemampuan analisis siswa (Yuliani, 2012), ada peningkatan hasil belajar dan kemampuan berpikir kreatif siswa dengan menerapkan pembelajaran menggunakan pendekatan keterampilan proses sains (Rahayu, Susanto, \& Yulianti, 2011). 


\section{Jurnal Pendidikan Fisika dan Keilmuan (JPFK), 4 (2), 2018 - 77}

Eli Sumiati, Damar Septian, F. Faizah

Modul merupakan salah satu bentuk bahan ajar cetak yang disajikan secara sistematis, sehingga penggunanya bisa belajar dengan atau tanpa guru (Mutmainah, 2016). Beberapa siswa menyamakan modul dengan buku. Kriteria buku yang baik yaitu mudah dipahami sehingga pemakainya tidak kesulitan dalam menggunakannya, terdapat keterangan yang membantu pemakainya dalam memahami informasi yang disajikan, terdapat gambar yang menarik minat pemakainnya, serta harus sesuai dengan kurikulum yang berlaku agar pngetahuan dan informasi yang didapat oleh pemakainnya tidak melenceng dari kurikuum yang berlaku serta sesuai dengan keutuhan dan tuntutan zaman (Kusuma, 2018). Pada konsep ini, modul dan buku memiliki kesamaan dalam penyajiannya agar menarik untuk dibaca. Keberadaan modul saat ini masih masih bersifat verbal atau tekstual sehingga peserta didik masih merasa kurang tertarik untuk membacanya (Yusro \& Sasono, 2016). Berdasarkan pemaparan di atas dapat disimpulkan bahwa modul merupakan salah satu bahan ajar alternatif yang dapat dikembangkan dalam menunjang proses belajar siswa.

Penelitian ini dilaksanakan di SMA Negeri 1 Panawangan, kabupaten Ciamis. Secara keseluruhan, fasilitas yang ada di sekolah sudah baik tetapi masih ada beberapa kekurangan, khususnya dalam menunjang materi fluida statis baik dari segi fasilitas untuk laboratorium maupun buku atau bahan ajar yang relevan. Buku yang ada di sekolah terbatas pemakaiannya yaitu hanya untuk di sekolah. Berdasarkan hasil analisis kebutuhan guru, dapat diketahui bahwa guru mengalami kendala dalam mengajarkan materi fluida statis kepada siswa sehingga siswa belum menguasai konsep fluida statis dengan baik. Berdasarkan hasil analisis kebutuhan siswa dapat diketahui bahwa sebagian besar siswa masih mengalami kesulitan dalam mempelajari materi fluida statis. Hasil wawancara menunjukkan bahwa masih ada kekurangan sarana dan prasarana untuk menunjang kegiatan belajar khususnya materi fluida statis.

Berdasarkan dari pemaparan di atas, upaya untuk memperbaiki dan meningkatkan mutu proses belajar mengajar di kelas harus selalu dilakukan. Salah satu upaya tersebut adalah dengan memilih bahan ajar dan metode/pendekatan/strategi yang tepat dalam pembelajaran. Bahan ajar modul dan pendekatan saintifik dapat dijadikan salah satu alternatif bahan ajar dan pendekatan pembelajaran. Oleh karena itu, Pengembangan modul fisika berbasis scientific approach dapat dijadikan alternatif dalam meningkatkan keterampilan proses sains siswa pada materi fluida statis.

\section{METODE}

Penelitian yang dilakukan merupakan jenis penelitian Research and Development (R\&D) dengan menggunakan model 4D yang dikemukakan oleh Thiagarajan, Semmel dan Semmel. Model ini terdiri atas 4 tahap pengembangan, yaitu define, design, develop, dan desseminate. Berikut merupakan uraian dari tahapan model 4D:

1. Define

$\begin{array}{ccc}\text { Pada tahap ini } & \text { dilakukan } \\ \text { pengumpulan } & \text { informasi } & \text { mengenai }\end{array}$ kebutuhan akan modul fisika, peninjauan aspek keterampilan proses sains, penggunaan media dalam proses pembelajaran, kesulitan/hambatan dalam proses belajar dan mengajar, serta ketersediaan alat dan penunjang penggunaan media pembelajaran melalui penyebaran angket analisis kebutuhan untuk guru dan siswa, serta wawancara tidak terstruktur.

2. Design

Pada tahap ini melakukan identifikasi KI dan KD yang dimunculkan pada materi Fluida Statis, mengumpulkan bahan/materi Fluida Statis, dan pemilihan format modul yang disesuaikan dengan analisis kebutuhan sebelumnya (termasuk konsep modul yang digunakan, pemilihan icon-icon untuk menunjukkan penegasan terhadap aspek scientific approach, penempatan gambar ilustrasi, pemilihan warna latar/layout, penyajian dan pemilihan kegiatan praktikum yang akan dilakukan).

3. Develop

Pada tahap ini dilakukan validasi modul oleh ahli materi, bahasa, dan media, serta didukung oleh penilaian dari praktisi (guru mata pelajaran fisika) dan teman sejawat terhadap produk yang 


\section{Jurnal Pendidikan Fisika dan Keilmuan (JPFK), 4 (2), 2018 - 78}

Eli Sumiati, Damar Septian, F. Faizah

dikembangkan, kemudian produk yang sudah divalidasi dan direvisi siap untuk diujicobakan baik secara terbatas maupun diperluas. Ujicoba lapangan terbatas diujicobakan pada 10 siswa dan ujicoba lapangan secara luas diujicobakan pada 27 siswa kelas XI MIPA 3 SMA Negeri 1 Panawangan tahun akademik 2017/2018. Data diambil dengan teknik tes dan angket. Data hasil keterampilan proses sains siswa dianalisis dengan uji $t$ dua sampel berpasangan menggunakan software IBM SPSS Statistics 19, uji $n$ gain score, dan uji effect size dari Cohen. Hasil uji coba lapangan digunakan sebagai pertimbangan untuk merevisi modul yang dikembangkan.

4. Desseminate

Setelah uji coba diperluas dan direvisi, tahap selanjutnya adalah tahap penyebaran. Modul disebar di beberapa sekolah lain untuk mengetahui efektifitas penggunaan modul pada materi fluida statis dalam meningkatkan keterampilan proses sains siswa.

\section{HASIL DAN PEMBAHASAN}

Hasil dari setiap tahapan prosedur pengembangan yang telah dilakukan adalah sebagai berikut:

1. Define (Pendefinisian)

a. Tahap Pengumpulan Informasi

Data tahap pengumpulan informasi didapatkan dari hasil wawancara dan analisis kebutuhan. Tahap analisis kebutuhan digunakan untuk mengetahui kategori kebutuhan siswa maupun guru terkait pengembangan modul. Modul yang akan dikembangkan berupa bahan ajar yang dapat dijadikan sebagai media pembelajaran. Dalam pembelajaran individual, bahan ajar dapat digunakan sebagai media utama dan alat monitoring dan evaluasi bagi siswa.

Hasil wawancara yang dilakukan secara tidak tersrtruktur terhadap guru, dapat disimpulkan bahwa: (1) kurikulum yang digunakan di SMA Negeri 1 Panawangan merupakan kurikulum 2013; (2) sekolah belum meninjau secara langsung aspek-aspek dalam keterampilan proses sains; (3) sekolah (khususnya guru mata pelajaran fisika) belum menggunakan modul sebagai bahan ajar; (4) bahan ajar yang digunakan berupa buku sekolah elektronik (BSE) yang disediakan oleh sekolah; (5) metode belajar yang digunakan yaitu metode ceramah, dan selebihnya siswa lebih banyak melakukan kegiatan mencatat materi. Nilai KKM mata pelajaran fisika kelas XI adalah 80; (6) hasil belajar siswa khususnya pada mata pelajaran fisika materi fluida statis di kelas XI MIPA 3 rata-rata belum mencapai nilai KKM; (7) kelengkapan laboratorium secara keseluruhan cukup lengkap, hanya saja masih terdapat kekurangan alat praktikum untuk menunjang praktikum fluida statis;(8) ketersediaan sumber belajar cukup memadai dengan adanya buku-buku relevan yang disediakan serta tersedianya fasilitas internet (WiFi) di sekolah tetapi buku tersebut hanya dapat digunakan di sekolah saja; (9) kondisi sekolah yang baik, aman dan kondusif baik dari segi sarana, prasarana maupun keadaan lingkungan, sehingga dapat terciptanya suasana belajar yang nyaman. Hanya saja masih ada kekurangan sarana dan prasarana untuk menunjang kegiatan belajar khususnya materi fluida statis.

Berdasarkan hasil analisis kebutuhan guru diketahui bahwa guru mengalami kendala dalam mengajarkan materi fluida statis kepada siswa sehingga siswa belum memahami konsep fluida statis dengan baik dan guru belum pernah mengajak siswa untuk melaksanakan praktikum baik itu di dalam kelas maupun di laboratorium karena adanya keterbatasan alat praktikum mengenai fluida statis. Di dalam sains terdapat serangkaian proses sains sehingga dengan praktikum proses sains menjadi semakin Nampak yang diharapkan akan terbentuk produk sains. Kegiatan praktikum khususnya pada fluida statis perlu dilaksanakan, apalagi bila meninjau kurikulum yang digunakan di sekolah yakni kurikulum 2013 yang identik dengan proses pembelajaran menggunakan pendekatan ilmiah, yang menurut Kemendikbud (2013) dimana salah satu langkahnya adalah kegiatan experimenting (Pendidikan \& Kebudayaan, 2013).

Berdasarkan hasil analisis kebutuhan siswa diketahui $42 \%$ siswa memiliki buku teks atau buku pegangan lain untuk belajar materi fluida statis di rumah, $54 \%$ siswa mengalami kesulitan memahami materi fluida statis melalui media dan metode yang diterapkan oleh guru, dan $58 \%$ siswa mengalami kesulitan dalam mempelajari materi fluida statis dari buku yang sudah 


\section{Jurnal Pendidikan Fisika dan Keilmuan (JPFK), 4 (2), 2018 - 79}

Eli Sumiati, Damar Septian, F. Faizah

disediakan di sekolah maupun buku/sumber belajar lain yang menjadi pegangan siswa, $100 \%$ siswa belum pernah melakukan praktikum mengenai fluida statis baik di dalam kelas maupun di luar kelas dan laboratorium. Hal ini menunjukkan bahwa salah satu faktor siswa kesulitan belajar adalah keterbatasannya media pembelajaran serta pemilihan variasi metode pembelajaran.

Pembelajaran fluida statis dianggap kurang berhasil bila tidak ditunjang dengan kegiatan praktikum/laboratorium (Yuliani, 2012). Hal ini disebabkan oleh keterbatasan peralatan laboratorium dan media untuk menyampaikan materi fluida statis. Sejalan dengan itu, berdasarkan hasil wawancara tidak terstruktur terhadap salah satu guru fisika, diketahui bahwa pelaksanaan pembelajaran fisika khususnya fluida statis di kelas tidak menggunakan metode khusus dan cenderung masih bersifat konvensional yaitu guru menjelaskan materi, siswa mendengarkan, dan mencatat materi. Metode mengajar yang dilaksanakan dengan proses pembelajaran monoton seperti mendengarkan, mencatat, sedikit bertanya, berdiskusi dan kurangnya peran aktif siswa cenderung mengakibatkan siswa menjadi pembelajar yang pasif (Sabil, 2013).

Selain itu, guru belum meninjau aspek keterampilan proses sains (KPS) dalam kegiatan belajar mengajar, adapun beberapa kesamaan aspek KPS yang tidak asing bagi guru dan siswa karena guru tidak mengetahui bahwa aspek yang pernah di ajarkan tersebut adalah aspek KPS. Menurut Funk, mengajar dengan keterampilan proses berarti memberi kesempatan kepada siswa bekerja dengan ilmu pengetahuan dan siswa merasa bahagia sebab mereka aktif dan tidak menjadi pembelajar yang pasif (Tawil \& Liliasari, 2014). Untuk itu, dengan meninjau keterampilan proses sains, siswa dapat mengembangkan kemampuannya serta menjadikannya menjadi pembelajar yang aktif.

Guru hanya menggunakan bukubuku yang disediakan dari sekolah yang hanya bisa dipakai di sekolah. Sedangkan siswa dirasa perlu untuk mempunyai buku atau sumber belajar lain yang bisa digunakan di rumah, dan juga bisa dikontrol oleh guru. Berdasarkan karakteristik kurikulum 2013, jenis bahan ajar yang seharusnya disusun adalah bahan ajar yang konstruktivis yang dapat digunakan sebagai media belajar di kelas, sekaligus dapat melatih kemandirian siswa dalam membangun konsepnya sendiri (Pranata, Mahanal, \& Lestari, 2016). Salah satu pemanfaatan media pembelajaran yang digunakan sebagai perantara dalam pembelajaran fisika adalah bahan ajar (Sukiminiandari, Budi, \& Supriyati, 2015). Berbagai bahan ajar dapat digunakan sebagai perantara dalam pembelajaran fisika, misalnya modul. Penggunaan modul di dalam kegiatan belajar mengajar tidak hanya memandang aktivitas guru semata, melainkan juga melibatkan siswa secara aktif dalam belajar.

Siswa perlu memiliki modul sehingga siswa memiliki buku ajar yang bervariasi atau referensi lain dalam belajar, yang diharapkan dapat mempermudah siswa dalam mempelajari dan memahamai materi (Sari \& Rachmawati, 2017). Semua siswa dan guru setuju jika dibuatkan suatu media pembelajaran fisika untuk materi fluida statis yang dapat digunakan sebagai alternatif sumber belajar dalam bentuk modul serta adanya peninjauan aspek keterampilan proses sains.

2. Design (Perancangan)

a. Tahap Pengembangan Produk Awal Tahapan perancangan dilakukan dengan cara mengidentifikasi KI dan KD yang dimunculkan pada materi fluida statis, mengumpulkan bahan/materi, dan memilih format modul yang disesuaikan dengan analisis kebutuhan sebelumnya (termasuk konsep modul yang digunakan, pemilihan icon-icon untuk menunjukkan penegasan terhadap aspek scientific approach, penempatan gambar ilustrasi, pemilihan warna latar, penyajian dan pemilihan kegiatan praktikum yang akan dilakukan). Sebelum menentukan materi pembelajaran, terlebih dahulu perlu diidentifikasi aspekaspek standar kompetensi dan kompetensi dasar yang harus dipelajari dan dikuasai siswa (Murniati \& Muslim, 2017).

Identifikasi Kompetensi Dasar menjadi acuan untuk pengembangan indikator-indikator yang harus dicapai oleh siswa. Kompetensi ini akan digunakan sebagai acuan dalam mengembangkan materi pada modul yang meliputi penyajian materi, kegiatan percobaan, kuis/evaluasi, aspek keterampilan proses sains yang akan ditinjau dan penyusunan soal aspek keterampilan 


\section{Jurnal Pendidikan Fisika dan Keilmuan (JPFK), 4 (2), 2018 - 80}

Eli Sumiati, Damar Septian, F. Faizah

proses sains. Kemudian, dibuatlah rencana pelaksanaan pembelajaran (RPP) dan silabus yang terlebih dahulu divalidasi oleh ahli pembelajaran.

Langkah penyusunan modul terdiri dari 3 bagian utama yang meliputi pendahuluan, isi, dan penutup (Nasional, 2008). Pada bagian pendahuluan, desain awal pada modul disesuaikan dengan hasil analisis kebutuhan. Kesesuaian media dengan siswa menjadi dasar pertimbangan utama sebab hampir tidak ada satu media yang dapat memenuhi semua tingkatan usia (Susilana \& Riyana, 2007). Oleh karena itu, hasil analisis kebutuhan menjadi rujukan pembuatan modul fisika berbasis scientific approach ini. Selain itu, karakteristik modul scientific approach ditampilkan dengan icon-nya masing-masing, dan untuk aspek keterampilan proses sains ditampilkan pada kegiatan kuis/evaluasi berupa essay. Hal ini dimaksudkan untuk memudahkan tercapainya pembuatan modul sesuai dengan basis yang akan digunakan serta mempermudah siswa dalam memahami langkah-langkah pembelajaran yang ada di dalam modul.

Penyusunan isi modul terdapat pada 5 kegiatan pembelajaran yang telah disusun berdasarkan submateri yang akan dipelajari siswa. Setiap kegiatan berisi langkah-langkah scientific approach yang dilakukan secara berkelompok. Untuk tambahan informasi, ditambahkan info mengenai aplikasi dari tiap sub materi, serta soal uji kompetensi. Kemudian pada bagian penutup berisi daftar pustaka dan glosarium. Di dalam modul berbasis scientific approach ini, disajikan menu video yang dapat diakses melalui barcode scanner untuk menambah informasi dan pengetahuan siswa mengenai materi fluida statis yang disajikan pada tiap sub pembahasan.

Alat evaluasi pembelajaran yang dipakai dalam modul adalah lembar soal evaluasi dengan bentuk soal essay. Selain itu, alat evaluasi dalam pembelajaran menggunakan dua tes yaitu pretest dan posttest. Tes disusun berdasarkan kompetensi dasar serta indikator pencapaian pembelajaran.

Hasil dari perancangan draft modul ini, terdapat saran perbaikan dari dosen pembimbing yaitu cover design yang dipakai terlalu monoton dan terlihat biasa serta saran untuk menampilkan gambar-gambar yang menarik dan kontekstual.

3. Develope (Pengembangan)

Tahap pengembangan pada penelitian ini didasarkan pada hasil validasi dari ahli materi, bahasa, media, serta didukung oleh penilaian dari praktisi (guru mata pelajaran fisika) dan teman sejawat.

Tabel 1. Hasil Validasi Ahli, Praktisi, dan Teman Sejawat

\begin{tabular}{|c|c|c|c|c|}
\hline \multirow[b]{2}{*}{ No. } & \multirow[b]{2}{*}{ Validator } & \multicolumn{2}{|c|}{ Skor } & \multirow[b]{2}{*}{ Kategori } \\
\hline & & $\begin{array}{l}\text { Rata- } \\
\text { rata }\end{array}$ & Max. & \\
\hline 1. & Ahli Media & 47 & 60 & Baik \\
\hline 2. & Ahli Materi & 63 & 84 & Baik \\
\hline 3. & Ahli Bahasa & 59 & 68 & $\begin{array}{l}\text { Sangat } \\
\text { Baik }\end{array}$ \\
\hline 4. & $\begin{array}{l}\text { Praktisi (Guru } \\
\text { Fisika) }\end{array}$ & 212 & 212 & $\begin{array}{l}\text { Sangat } \\
\text { Baik }\end{array}$ \\
\hline 5. & Teman Sejawat & 164 & 212 & $\begin{array}{c}\text { Sangat } \\
\text { baik }\end{array}$ \\
\hline
\end{tabular}

Hasil validasi dari dosen pembimbing yang sudah diperbaiki, kemudian dilakukan validasi oleh beberapa validator ahli meliputi ahli media, materi, bahasa, praktisi (guru fisika), dan teman sejawat. Masing-masing validasi didapatkan hasil presentase keidealan dengan kategori ideal secara berturut-turut adalah 79\% (Sangat Baik), $75 \%$ (Baik), $87 \%$ (Sangat Baik), $100 \%$ (Sangat Baik), dan 77\% (Sangat
Baik) dengan rata-rata 83,6 \% (Sangat Baik). Pada tahap validasi modul, terdapat beberapa saran perbaikan yang diberikan oleh validator ahli, praktisi (guru fisika), dan teman sejawat yaitu adanya perbaikan beberapa desain dan layout pada bab kapilaritas, daftar pustaka dan glosarium sudah dicantumkan, istilah untuk "molekul yang ditarik oleh sesama molekul' sudah 


\section{Jurnal Pendidikan Fisika dan Keilmuan (JPFK), 4 (2), 2018 - 81}

Eli Sumiati, Damar Septian, F. Faizah

diperbaiki dari "gaya adhesi" menjadi "gaya kohesi".

Tahap selanjutnya yaitu uji coba terbatas yang sampelnya diambil melalui teknik purposive sampling. Purposive sampling adalah teknik pengambilan sampel secara sengaja dengan maksud peneliti menentukan sendiri sampel yang diambil karena ada pertimbangan tertentu (Ulwan, 2015). Cara pengambilan dilakukan dengan mengambil 10 orang siswa sebagai sampel dengan ketentuan 5 orang siswa laki-laki dan 5 orang siswa perempuan melalui nilai maksimal, minimal, kuartil 1, kuartil 2, dan kuartil 3 dari nilai fluida statis siswa.

Pelaksanaan uji coba terbatas ini bertujuan untuk mengetahui gambaran umum kualitas modul fisika berbasis scientific approach serta kelebihan dan kelemahan modul sementara sebelum diujicobakan secara lebih luas dalam pembelajaran di kelas.

Tabel 2. Hasil Respon Siswa Uji Coba Terbatas

\begin{tabular}{cccc}
\hline Aspek Penilaian & Rata-rata/responden & $\begin{array}{c}\text { Skor } \\
\text { Maksimum }\end{array}$ & Kategori \\
\hline $\begin{array}{c}\text { Daya Tarik Modul } \\
\text { Mingkat Pemahaman Penggunaan }\end{array}$ & 25,5 & 32 & Positif \\
\hline $\begin{array}{c}\text { Tingkat Pemahaman Penggunan } \\
\text { Scientific Approach }\end{array}$ & 20 & 24 & Sangat Positif \\
\hline $\begin{array}{c}\text { Tingkat Pemahaman Penggunaan } \\
\text { Keterampilan Proses Sains }\end{array}$ & 10,1 & 12 & Sangat Positif \\
\hline Rata-Rata Jumlah Skor & 9,5 & 12 & Positif \\
\hline
\end{tabular}

Antusiasme siswa untuk mempelajari modul terlihat dari pertemuan pertama ketika sosialisai tentang adanya penelitian terhadap pengembangan modul fisika dengan kategori "Positif" pada aspek daya tarik modul. Ketika modul pertamakali didistribusikan pada siswa, hal pertama yang menarik perhatian siswa adalah tema modul yang mengusung tema colorfull dengan memunculkan gambar sebagai ilustrasi materi, serta adanya fasilitas video dengan barcode yang dapat diakses melalui smartphone siswa. Dengan adanya fasilitas video tersebut menjadikan siswa lebih tertarik untuk mempelajari modul. Bahkan, kebanyakan siswa langsung mencoba mengakses video tersebut dan memperhatikannya dengan seksama apa yang digambarkan dalam video tersebut.

Pada tahap uji coba secara terbatas, beberapa siswa mengalami kendala ketika mempelajari modul, terutama pada tahap kegiatan mengamati dan menanya. Siswa merasa kebingungan dalam mengamati gambar dan mengajukan pertanyaan. Siswa masih ragu dan merasa malu dalam mengajukan pertanyaan. Rasa percaya diri terutama dalam hal komunikasi merupakan salah satu sikap yang harus ditanamkan siswa sejak dini (Faizah, Miswadi, \& Haryani,
2013). Sikap tersebut merupakan salah satu kualitas seseorang yang tak terwujud (intangible) yang berada di peringkat atas dan sangat menunjang kesuksesan seseorang di manapun berada dan dalam suatu pekerjaan atau biasa disebut dengan soft skill. Sehingga, peneliti harus memberikan clue dan arahan untuk menstimulasi siswa dalam mengajukan pertanyaan dan apa saja yang dapat diamati. Secara umum, ketika pembelajaran modul fisika dilakukan dengan cara diskusi, siswa dapat berkomunikasi dengan teman kelompoknya untuk saling mencari tahu jawaban dari pertanyaan di dalam modul. Dengan diskusi, siswa dapat terlatih untuk menyatakan pendapat dan gagasan secara verbal dan dapat melatih untuk membiasakan diri bertukar pikiran dalam mengatasi setiap permasalahan dengan menghargai pendapat orang lain (Yamin \& Maisah, 2009).

Berdasarkan angket penilaian siswa, disimpulkan bahwa modul fisika berbasis scientific approach yang dikembangkan mendapatkan respon "Sangat Positif" dari 10 orang siswa yang menjadi responden. Berdasarkan hal tersebut, modul fisika berbasis scientific approach memberikan dampak positif dan manfaat untuk 


\title{
Jurnal Pendidikan Fisika dan Keilmuan (JPFK), 4 (2), 2018 - 82
}

\author{
Eli Sumiati, Damar Septian, F. Faizah
}

meningkatkan keterampilan proses sains siswa pada materi fluida statis.

Tahap selanjutnya tahap uji coba diperluas. Uji coba diikuti oleh 27 orang siswa dengan membaginya menjadi 7 kelompok, dan tiap kelompok beranggotakan 3-4 orang. Setiap kelompok mendapatkan perlakuan yang sama pada setiap pertemuan. Uji coba diperluas dilakukan pada tanggal 9 Januari - 16 Januari 2018 dengan pre test dilaksanakan pada tanggal 9 Januari dan post test pada tanggal 16 Januari. Data yang diperoleh pada tahap uji coba diperluas adalah sebagai berikut:

a. Data Keterampilan Proses Sains Siswa

Data keterampilan proses sains siswa diperoleh dari hasil pre test dan post test dapat dilihat pada tabel 3 dan hasil analisis data tahap uji coba diperluas dapat dilihat pada tabel 4.

Tabel 3. Deskripsi Data Keterampilan Proses Sains Siswa Uji Coba Diperluas

\begin{tabular}{ccccccc}
\hline Jenis Tes & Jumlah Siswa & Mean & Standar Deviasi & Median & Min & Maks \\
\hline Pre Test & 27 & 37,04 & 10,58 & 40,00 & 20,00 & 55,00 \\
\hline Post Test & 27 & 60,74 & 23,07 & 55,00 & 30,00 & 95,00 \\
\hline
\end{tabular}

Peningkatan hasil tes rata-rata yang signifikan mencapai $60,98 \%$ diperoleh dari perkembangan siswa dalam mempelajari modul selama tiga kali pertemuan. Nilai tes yang diperoleh ketika pre test masih rendah dikarenakan siswa tidak mengetahui akan diadakan pre test dan tidak ada persiapan siswa untuk belajar. Hal ini dimaksudkan untuk mengetahui sejauh apa pemahaman siswa terhadap materi fluida statis dalam me review ulang pelajaran yang sudah didapat.

Pada pertemuan pertama, guru membagikan modul dan memberi instruksi mengenai petunjuk penggunaan modul dan kegiatan pembelajaran yang akan dilaksanakan. Materi yang dibahas mengenai massa jenis dan tekanan. Siswa sangat antusias dalam melaksanakan setiap tahapan kegiatan yang disediakan dalam modul. Siswa mampu membangun kerjasama serta komunikasi antar anggota kelompok sehingga kegiatan belajar berjalan dengan baik. Siswa secara aktif dapat merespon apa yang disajikan dalam modul serta mampu menjawab setiap pertanyaan di dalamnya. Meskipun terdapat beberapa kendala diantaranya pada kegiatan praktikum massa jenis, beberapa peralatan tidak dapat dipenuhi dikarenakan adanya miss komunikasi antara peneliti dan guru fisika mengenai pemakaian alat dan ruang laboratorium yang ternyata sudah dipakai oleh guru lain. Tetapi, hal tersebut sedikitnya dapat teratasi oleh penggunaan akses video yang terdapat dalam modul.

Pada pertemuan kedua, materi yang dibahas mengenai hukum hidrostatis, hukum Archimides, dan hukum Pascal. Pada pertemuan ini, terjadi kendala dari beberapa siswa mengenai kegiatan pembelajaran yang dinilai membosankan karena setiap tahapan kegiatan harus dicantumkan hasilnya didalam modul dalam bentuk tertulis. Menurut siswa, kegiatan tersebut dianggap cukup membosankan apabila kegiatan bertanya harus ditulis secara tertulis dan berulangulang. Untuk itu, peneliti memberikan arahan mengenai setiap kegiatan dalam modul dan ketentuannya yang disesuaikan dengan basis scientific approach. Rasa bosan yang dikeluhkan oleh beberapa siswa dapat kembali menjadi respon positif setelah melaksanakan beberapa kegiatan praktikum terlebih saat melaksanakan praktikum hukum Pascal, yaitu membuat alat berupa pompa hidrolik yang terbuat dari stick ice cream. Pada materi hukum hidrostatis, hanya dibahas sampai pada kegiatan mengamati dan mengkomunikasikan saja. Hal ini dilakukan karena adanya keterbatasan waktu dalam proses kegiatan belajar mengajar tersebut.

Pada pertemuan ketiga, tidak ada kendala yang berarti. Siswa sudah terbiasa dan paham mengenai alur dan kegiatan yang ada di dalam modul. Hanya saja, ada kendala pada wilayah teknis yaitu siswa mengalami keterlambatan dalam memulai pembelajaran dikarenakan adanya kegiatan perpisahan salah satu guru yang merupakan guru favorit bagi kelas XI MIPA 3. Siswa meminta izin untuk melaksanakan musofahah dan berfoto dengan guru yang bersangkutan. Selain itu, beberapa siswa kurang siap dalam memulai pembelajaran dikarenakan siswa mengalami kelelahan setelah kegiatan olehraga serta terjadi kemoloran karena siswa harus mengganti seragam terlebih dahulu. Tetapi, 


\section{Jurnal Pendidikan Fisika dan Keilmuan (JPFK), 4 (2), 2018 - 83}

Eli Sumiati, Damar Septian, F. Faizah

siswa tetap antusias terhadap pembelajaran dengan modul fisika berbasis scientific approach. Materi yang dibahas dalam pertemuan ini adalah tegangan permukaan, viskositas, dan kapilaritas. Untuk materi tegangan permukaan, siswa merasa antusias dengan kegiatan praktikum yang dilakukan yaitu membuat rekasi warna dengan tetesan detergen yang menimbulkan percampuran warna seperti kembang api.
Pada pembelajaran modul berbasis scientific approach ini, guru bertindak sebagai fasilitator. Guru akan membantu siswa jika mengalami kesulitan dalam mempelajari modul. Tetapi secara keseluruhan, siswa mempelajari keseluruhan materi di dalam modul secara mandiri dan berdiskusi dengan teman sekelompoknya.

Tabel 4. Hasil Analisis Data Kognitif Siswa Uji Coba Diperluas

\begin{tabular}{lllcc}
\hline \multicolumn{1}{c}{ Pengujian } & \multicolumn{1}{c}{ Jenis Uji } & \multicolumn{1}{c}{ Hasil } & Keputusan & Kesimpulan \\
\hline Reliabilitas & Cronbach Alpha & alpha $=0,476$ & $\begin{array}{c}0,476>\text { r tabel } \\
(0,381)\end{array}$ & Reliabel \\
\hline Normalitas & Kolmogorof-Smirnof & $\begin{array}{l}\text { Sig. Pre test }=0,541 \\
\text { Sig. Post test }=0,427\end{array}$ & Ho diterima & Data Normal \\
\hline Homogenitas & Levene's Test & Sig. $=0,344$ & Ho diterima & $\begin{array}{c}\text { Data } \\
\text { Homogen }\end{array}$ \\
\hline $\begin{array}{l}\text { Data Pre test- } \\
\text { Post Test }\end{array}$ & Paired Sample t-test & $\begin{array}{l}\mathrm{t}_{\text {hitung }}=-5,409 \\
\mathrm{df}=26 \\
\mathrm{p}=0,000\end{array}$ & Ho ditolak & $\begin{array}{c}\text { Hasil tidak } \\
\text { sama (ada } \\
\text { perbedaan) }\end{array}$ \\
\hline
\end{tabular}

Data yang diuji menggunakan aplikasi IBM Statistics SPSS 19 ini menunjukkan bahwa soal yang digunakan mempunyai tingkat kekonsistensian soal yang sangat tinggi, data terdistribusi secara normal, varian data homogen atau varian data setiap sampel sama, dan terdapat perbedaan yang signifikan antara hasil keterampilan proses sains siswa sebelum dan sesudah menggunakan modul yang dikembangkan.

Tabel 5. Hasil Respon Siswa Uji Coba Luas

\begin{tabular}{lccc}
\hline \multicolumn{1}{c}{ Aspek Penilaian } & $\begin{array}{c}\text { Skor yang } \\
\text { diperoleh }\end{array}$ & $\begin{array}{c}\text { Skor } \\
\text { Maksimum }\end{array}$ & $\begin{array}{c}\text { Kategori } \\
\text { Respon }\end{array}$ \\
\hline Daya Tarik Modul & 26,89 & 32 & Sangat Positif \\
\hline Tingkat Pemahaman Penggunaan Modul & 20,67 & 24 & Sangat Positif \\
\hline $\begin{array}{l}\text { Tingkat Pemahaman Penggunan Scientific } \\
\text { Approach }\end{array}$ & 10,04 & 12 & Sangat Positif \\
\hline $\begin{array}{l}\text { Tingkat Pemahaman Penggunaan } \\
\text { Keterampilan Proses Sains }\end{array}$ & 10,26 & 12 & Sangat Positif \\
\hline JUMLAH & 67,85 & 80 & Sangat Positif \\
\hline & Kategori Respon Siswa & & Sangat Positif \\
\hline
\end{tabular}

Dari hasil angket respon siswa terhadap modul yang dikembangkan menunjukkan bahwa, penilaian siswa "Sangat Positif". Total nilai rata-rata yang diperoleh sebesar 67,85 (nilai maksimum 80) dengan persentase $85 \%$. Siswa menilai daya tarik modul "Sangat Positif" dengan persentase $84 \%$. Hasil ini menunjukkan bahwa modul yang digunakan menarik untuk dipelajari dan dapat memotivasi siswa dalam mempelajari fluida statis. Selain itu, siswa mulai memahami modul sebagai variasi belajar baru.
Tingkat pemahaman penggunaan modul sebesar $86 \%$ menunjukkan bahwa modul yang digunakan mudah dipahami siswa. Dengan kurikulum yang identik dengan penggunaan scientific approach, siswa tidak terlalu kesulitan dalam mengaplikasikan scientific approach yang ada di dalam modul, sehingga tingkat pemahaman scientific approach siswa memperoleh respon "Sangat Positif" dengan persentase $84 \%$, dan tingkat pemahaman keterampilan proses sains (KPS) siswa sebesar $86 \%$. Hal ini dikarenakan siswa 


\section{Jurnal Pendidikan Fisika dan Keilmuan (JPFK), 4 (2), 2018 - 84}

Eli Sumiati, Damar Septian, F. Faizah

pernah menerima materi dengan beberapa aspek KPS, tetapi guru tidak mengetahui bahwa aspek yang diajarkannya merupakan aspek KPS.

Penyajian materi yang bersifat ilmiah membuat siswa menemukan sendiri fakta, konsep, ataupun prosedur mengenai pengetahuan fisika itu sendiri, khususnya pada materi fluida statis. Siswa secara aktif mencari tahu melalui berbagai aktvitas proses sains di dalam pembelajaran,

Tabel 6.Keefektifan Penerapan Modul Fisika Berbasis Scientific Approach Untuk Meningkatkan Keterampilan Proses Sains Siswa

\begin{tabular}{ccccc}
\hline No. & Jenis Test & Rata-Rata Hasil Test & Keefektifan Relatif (\%) & Kategori \\
\hline 1. & Pre Test & 37,04 & 64 & Efektif \\
\hline 2. & Post Test & 60,74 & & \\
\hline
\end{tabular}

Peningkatan nilai pre test dan post test ini merupakan hasil keterampilan proses sains dalam mempelajari materi fluida menggunakan modul berbasis scientific approach.

Tabel 7. Effect Size

Di samping itu, besar nilai keefektifan diperoleh melalui persamaan effect size dari Cohen yang disajikan pada tabel 7. sebagaimana para ilmuan kerjakan, sehingga siswa merasakan kebermanfaatan dan kebermaknaan ilmu yang ia pelajari. Materi pelajaran akan lebih berarti jika siswa mempelajari materi pelajaran yang disajikan melalui konteks kehidupan mereka, dan menemukan arti di dalam proses pembelajarannya, sehingga pembelajaran akan lebih berarti dan menyenangkan (Trianto, 2009).

\begin{tabular}{|c|c|c|c|c|}
\hline Skor Tes & Pre Test & Post Test & $d$ & Kategori \\
\hline Rata-Rata & 37,04 & 60,74 & \multirow{2}{*}{1,32} & Besar \\
\hline Standar Deviasi & 10,585 & 23,068 & & \\
\hline
\end{tabular}

Nilai dengan kategori effect size yang "Besar" yaitu 1,32 diperoleh karena sebelumnya secara tidak langsung guru sudah meninjau aspek-aspek yang sebenarnya termasuk ke dalam aspek KPS. Selain itu, siswa tidak asing lagi dengan beberapa aspek KPS yang ditinjau di dalam penelitian. Di samping itu, modul yang digunakan untuk penelitian dapat dibawa pulang oleh siswa ke rumah masing-masing sehingga ada kemungkinan siswa untuk mempelajari dan mencoba memahami isi dari modul tersebut. Oleh karena itu, ketika dibahas di sekolah, beberapa siswa sudah memahami materi yang akan disampaikan.

Selain itu, peningkatan hasil keterampilan proses sains (KPS) siswa dilihat berdasarkan nilai gain score.

$\underline{\text { Tabel 8. Peningkatan Keterampilan Proses Sains Siswa }}$

\begin{tabular}{cccc}
\hline \multirow{2}{*}{ Rentang } & \multirow{2}{*}{ Kategori } & \multicolumn{2}{c}{ Hasil Tes } \\
\cline { 3 - 4 } & & Jumlah Siswa & Presentase \\
\hline $\mathrm{g} \geq 0,7$ & Tinggi & 10 & $37 \%$ \\
\hline $\begin{array}{c}0,3 \leq \mathrm{g}< \\
0,7\end{array}$ & Sedang & 6 & $22 \%$ \\
\hline $\mathrm{g}<0,3$ & Rendah & 11 & $41 \%$ \\
\hline
\end{tabular}

Dengan rata-rata gain yang didapat sebesar 0,4 dengan kategori "Sedang". Hal ini dikarenakan adanya beberapa kekurangan dalam proses KBM, baik dari segi waktu maupun kendala teknis lainnya, adanya kemungkinan dari pembahasan aspek KPS yang kurang banyak, serta penggunaan aspek KPS yang hanya sebatas di soal saja tetapi tidak untuk dijadikan sebagai pendekatan pembelajaran. Selain itu, penilaian mengenai 


\section{Jurnal Pendidikan Fisika dan Keilmuan (JPFK), 4 (2), 2018 - 85}

Eli Sumiati, Damar Septian, F. Faizah

KPS hanya dilihat dari hasil pre test dan post test, tidak dari hasil observasi untuk mengetahui keterampilan proses secara afektif dan psikomotorik. Penilaian mengenai keterampilan dan kreativitas dapat dilihat dari aspek psikomotorik dan afektif yang

Tabel 9. Perbandingan Nilai Fluida Statis Sebelum dan Sesudah Penelitian

\begin{tabular}{lcccc}
\hline KKM & $\begin{array}{c}\text { Ulangan } \\
\text { Harian }\end{array}$ & $\begin{array}{c}\text { Post } \\
\text { Test }\end{array}$ & $\begin{array}{c}\text { Kenaikann } \\
(\%)\end{array}$ \\
\hline $\begin{array}{l}\text { Rata-Rata Skor } \\
\text { Tes }\end{array}$ & 80 & 47,44 & 60,74 & $13 \%$ \\
\hline Jumlah Siswa yang lulus & 0 & 10 & $10 \%$ \\
\hline
\end{tabular}

Persentase ketuntasan belajar siswa sebesar $37 \%$ terjadi karena keterbatasan waktu penelitian sehingga proses KBM berjalan kurang maksimal. Berdasarkan perbandingan hasil belajar siswa dari guru sebelumnya dengan hasil post test setelah menggunakan modul cenderung mengalami peningkatan karena proses KBM materi diukur melalui observasi kegiatan pembelajaran yang berlangsung (Yusro, 2017).

Tabel 10. Hasil Penilaian Modul Tahap Desseminate

\begin{tabular}{|c|c|c|c|c|c|c|}
\hline \multirow{2}{*}{\multicolumn{2}{|c|}{ Aspek Penilaian }} & \multicolumn{2}{|c|}{ Validator } & \multirow{2}{*}{ Skor Rata-Rata } & \multirow{2}{*}{ Skor Maksimum } & \multirow{2}{*}{ Kategori } \\
\hline & & 1 & 2 & & & \\
\hline \multirow{4}{*}{ Materi } & 1 & 14 & 14 & 14 & 16 & Sangat Baik \\
\hline & 2 & 6 & 8 & 7 & 8 & Sangat Baik \\
\hline & 3 & 40 & 42 & 41 & 48 & Sangat Baik \\
\hline & 4 & 12 & 10 & 11 & 12 & Sangat Baik \\
\hline \multirow{7}{*}{ Bahasa } & 1 & 16 & 14 & 15 & 16 & Sangat Baik \\
\hline & 2 & 12 & 10 & 11 & 12 & Sangat Baik \\
\hline & 3 & 6 & 8 & 7 & 8 & Sangat Baik \\
\hline & 4 & 8 & 8 & 8 & 8 & Sangat Baik \\
\hline & 5 & 6 & 8 & 7 & 8 & Sangat Baik \\
\hline & 6 & 8 & 8 & 8 & 8 & Sangat Baik \\
\hline & 7 & 8 & 8 & 8 & 8 & Sangat Baik \\
\hline \multirow{4}{*}{ Media } & 1 & 24 & 22 & 23 & 24 & Sangat Baik \\
\hline & 2 & 12 & 12 & 12 & 12 & Sangat Baik \\
\hline & 3 & 16 & 14 & 15 & 16 & Sangat Baik \\
\hline & 4 & 8 & 8 & 8 & 8 & Sangat Baik \\
\hline \multicolumn{2}{|c|}{ JUMLAH } & 196 & 194 & 195 & 212 & \\
\hline \multicolumn{6}{|c|}{ Kategori Modul } & Sangat Baik \\
\hline
\end{tabular}

Modul diberikan pada guru-guru fisika agar modul dapat dinilai oleh mereka melalui angket yang telah disediakan. Pada penilaian modul ini, guru terlihat tertarik dengan modul yang dikembangkan oleh peneliti, apalagi ketika ada peninjauan aspek keterampilan proses sains dan akses barcode di dalamnya. Hal tersebut menjadi salah satu daya tarik serta contoh penilaian baru mengenai aspek keterampilan proses sains yang dapat dikembangkan lagi dan fluida statis merupakan kegiatan belajar pengulangan atau mengulas kembali.

4. Desseminate (Penyebaran)

Tahap penyebaran dilakukan melalui penilaian angket oleh dua orang validator yaitu guru fisika dari SMA Negeri 8 Kota Cirebon. Hasil penilaian angket modul fisika disajikan pada tabel 10 . digunakan pada proses pembelajaran lainnya. Hasil dari penilaian menunjukkan bahwa modul fisika berbasis scientific approach tergolong "Sangat Baik" dengan persentase keidealan $92 \%$. Berdasarkan hasil penilaian dari guru-guru fisika dapat disimpulkan bahwa modul fisika berbasis scientific approach dinilai layak dan relevan jika digunakan dalam proses pembelajaran di instansi sekolah lainnya. 


\section{Jurnal Pendidikan Fisika dan Keilmuan (JPFK), 4 (2), 2018 - 86}

Eli Sumiati, Damar Septian, F. Faizah

Berdasarkan hasil penelitian, maka perlu dilakukan beberapa hal sebagai upaya pemanfaatan produk dan pengembangan produk lebih lanjut antara lain: (1) media pembelajaran fisika berbasis scientific approach disarankan untuk dimanfaatkan secara lebih luas dan lebih optimal oleh guru fisika SMA khususnya kelas XI; (2) media pembelajaran fisika berbasis scientific approach didesain untuk pembelajaran di kelas maupun pembelajaran mandiri di rumah sehingga guru harus mengontrol hasil lembar tugas pembelajaran media agar pembelajaran lebih optimal. Untuk pengembangan produk lebih lanjut, kegiatan pengembangan media pembelajaran fisika berbasis scientific approach dilanjutkan dengan pembelajaran fisika pada KD yang lain, aspek keterampilan proses sains yang lain, serta tema layout yang digunakan pada modul bisa divariasikan lagi dengan tema seperti abstract, anime, scientists, technology, environment, dll

\section{KESIMPULAN}

Berdasarkan hasil analisis data dan pembahasan yang telah dilakukan dapat disimpulkan bahwa:

(1) karakteristik modul fisika berbasis scientific approach yang dikembangkan menyajikan materi yang disesuaikan dengan langkah ilmiah dengan fitur akses video. Modul fisika berbasis scientific approach menuntut siswa untuk berperan aktif, membangun imajinasi, dan wawasan pengetahuan siswa dalam kegiatan mengamati, menanya, mencoba, mengasosiasi, dan mengkomunikasikan melalui penyajian ilustrasi materi/soal dalam bentuk gambar dan penyajian tambahan informasi melalui akses video dengan barcode; (2) keefektifan modul fisika berbasis scientific approach untuk meningkatkan keterampilan proses sains siswa pada materi fluida statis dapat dikatakan "Efektif". Hal ini didasarkan pada perolehan nilai kefektifan relatif sebesar 64\% dengan kategori "efektif" dengan perolehan nilai effect size dari Cohen sebesar 1,32 dengan kategori nilai effect size yang "Besar", artinya adanya suatu pengaruh yang besar dari modul terhadap peningkatan keterampilan proses sains siswa dengan peningkatan KPS rata-rata siswa melalui gain score sebesar 0,40 dengan kategori peningkatan "Sedang".

\section{DAFTAR PUSTAKA}

Arsyad, A. (2011). Media pembelajaran. Jakarta: PT Raja Grafindo Persada.

Arumsari, L. T., Rosilawati, I., \& Kadaritna, N. (2016). Pengembangan Instrumen Asesmen Keterampilan Proses Sains Pada Materi Teori Tumbukan. Jurnal Pendidikan dan Pembelajaran Kimia, 5(1), 140-151.

Faizah, Miswadi, S. S., \& Haryani, S. (2013). Pengembangan Perangkat Pembelajaran Berbasis Masalah untuk Meningkatkan Soft Skill dan Pemahaman Konsep. Jurnal Pendidikan IPA Indonesia, 2(2).

Giantera, D. R. (2013). Pengaruh Fasilitas Belajar dan Motivasi Belajar Terhadap Hasil Belajar Siswa Mata Pelajaran Peralatan Kantor Pada Siswa Kelas X Program Keahlian Administrasi Perkantoran SMK Cokroaminoto 1 Banjarnegara. Universitas Negeri Semarang.

Herdianto, H. (2014). Identifikasi Profil Berpikir Kritis Siswa dalam Pembelajaran Fluida Statis dengan Modifikasi High- $\alpha$ Binaural Beats dan Guided Problem Solving. Inovasi Pendidikan Fisika, 3(2).

Indonesia, R. (2005). Peraturan Pemerintah Republik Indonesia nomor 19 tahun 2005 tentang standar nasional pendidikan.

Kusuma, D. (2018). Analisis Keterbacaan Buku Teks Fisika SMK Kelas X. Jurnal Pendidikan Fisika dan Sains (JPFS), 1(1), 14-21.

Mulyanto, E. (2016). Pengelolaan Bengkel Teknik Mekatronika SMK Negeri 2 Sukoharjo Tahun 2016. Universitas Muhammadiyah Surakarta.

Murniati, M., \& Muslim, M. (2017). Pengembangan Bahan Ajar Mata 


\section{Jurnal Pendidikan Fisika dan Keilmuan (JPFK), 4 (2), 2018 - 87}

Eli Sumiati, Damar Septian, F. Faizah

Kuliah Mekanika Berdasarkan Analisis Kompetensi. Jurnal Pendidikan Fisika dan Keilmuan (JPFK), 1(2), 67-73.

Mutmainah, S. (2016). Penggunaan Modul Fisika Scientific Approach Materi Fluida Statis untuk Meningkatkan Kemampuan Kognitif dan Komunikasi Ilmiah Siswa Kelas X MIA 5 Sman 2 Surakarta Tahun Pelajaran 2014/2015.

Nasional, D. P. (2008). Panduan pengembangan bahan ajar. Jakarta: Depdiknas.

Pendidikan, K., \& Kebudayaan, R. I. (2013). Permendikbud nomor 81A tahun 2013 Tentang Implementasi Kurikulum. Jakarta: Kementrian Pendidikan dan Kebudayaan.

Pranata, B. D., Mahanal, S., \& Lestari, U. (2016). Pengembangan Modul Pembelajaran Biologi Berbasis Discovery Inquiry pada Materi Sistem Reproduksi untuk Siswa Kelas XI SMA. SKRIPSI Jurusan BiologiFakultas MIPA UM.

Rahayu, E., Susanto, H., \& Yulianti, D. (2011). Pembelajaran sains dengan pendekatan keterampilan proses untuk meningkatkan hasil belajar dan kemampuan berpikir kreatif siswa. Jurnal Pendidikan Fisika Indonesia, $7(2)$.

Sabil, H. (2013). Meningkatkan Hasil Belajar Matematika Siswa Melalui Pembelajaran Aktif Model Jigsaw Pada Materi Himpunan di Kelas VII SMPN 7 Muaro Jambi. EDUMATICA| Jurnal Pendidikan Matematika, 3(2).

Sari, R. D. M., \& Rachmawati, L. (2017). Pengembangan Modul Pembelajaran Berbasis Problem Based Learning Pada KD Mendeskripsikan Bank Sentral, Sistem Pembayaran dan Alat Pembayaran dalam Perekonomian Indonesia Kelas $\mathrm{X}$ IIS SMAN 1 Krembung. Jurnal Pendidikan Ekonomi (JUPE), 5(3).

Satria, H., \& Handhika, J. (2015).
Pembelajaran Fisika Menggunakan Modul Berbasis Scientific Approach Bermuatan Pendidikan Karakter Pada Materi Termodinamika. In Prosiding: Seminar Nasional Fisika dan Pendidikan Fisika (Vol. 6).

Septian, D. (2018). Pembelajaran IPA dengan Learning Cycle Berbantuan Multimedia Interaktif ditinjau dari Pengetahuan Awal dan Gaya Belajar Siswa. Jurnal Pendidikan Fisika dan Sains (JPFS), 1(1), 1-13.

Septian, D., Cari, \& Sarwanto. (2017). Pengembangan Multimedia Interaktif Berbasis Learning Cycle Pada Materi Alat Optik Menggunakan Flash dalam Pembelajaran IPA SMP Kelas VIII. Jurnal Inkuiri, 6(1), 45-60. Diambil dari https://goo.gl/a1MLwR

Sukiminiandari, Y. P., Budi, A. S., \& Supriyati, Y. (2015). Pengembangan Modul Pembelajaran Fisika denganpendekatan Saintifik. In Prosiding Seminar Nasional Fisika (EJournal) (Vol. 4, hal. SNF2015-II).

Susilana, R., \& Riyana, C. (2007). Media pembelajaran. Bandung: CV Wacana Prima.

Tawil, M., \& Liliasari. (2014). KeterampilanKeterampilan Sains dan Implementasinya dalam Pembelajaran IPA. Makassar: UNM.

Trianto. (2009). Mendesain Model Pembelajaran Inovatif-Progresif. Jakarta: Kencana.

Ulwan, M. N. (2015). Teknik pengambilan sampel dengan metode purposive sampling. Artikel diakses pada tanggal, 25 .

Yamin, M., \& Maisah, M. D. (2009). Manajemen Pembelajaran Kelas: Strategi Meningkatkan Mutu Pembelajaran. Jakarta: Gaung Persada.

Yuliani, H. (2012). Pembelajaran Fisika dengan Pendekatan Keterampilan 
Jurnal Pendidikan Fisika dan Keilmuan (JPFK), 4 (2), 2018 - 88

Eli Sumiati, Damar Septian, F. Faizah

Proses dengan Metode Eksperimen dan Demonstrasi Ditinjau dari Sikap Ilmiah dan Kemampuan Analisis (Studi pada Materi Pembelajaran Fluida Statis untuk Siswa Kelas XI Semester 2 SMA Negeri 1 Jakenan Pati T. UNS (Sebelas Maret University).

Yusro, A. C. (2015). Pengembangan Perangkat Pembelajaran Fisika Berbasis SETS Untuk Meningkatkan Kemampuan Berpikir Kreatif Siswa. Jurnal Pendidikan Fisika dan Keilmuan (JPFK), 1(2), 61-66.

Yusro, A. C., \& Sasono, M. (2016). Penggunaan modul ilustratif berbasis inkuiri terbimbing pokok bahasan kinematika gerak lurus untuk meningkatkan hasil belajar dan kemandirian siswa kelas VII SMPN 14 Madiun. Jurnal Pendidikan Fisika Dan Keilmuan (JPFK), 2(1), 29-35. 